\title{
Lantana Lace Bug, Teleonemia scrupulosa Stål (Insecta: Hemiptera: Tingidae) ${ }^{1}$
}

\author{
D. H. Habeck, F. W. Mead and T. R. Fasulo ${ }^{2}$
}

\section{Introduction}

The lantana lace bug, Teleonemia scrupulosa Stål, often causes extensive damage to lantana, Lantana camara L. Although lantana is sometimes used as an ornamental, it is usually considered a weed. It often forms spiny, dense, impenetrable thickets covering large areas of valuable land. The lantana lace bug has been introduced into many countries as a biological control agent to combat lantana.

\section{Distribution}

The lantana lace bug ranges naturally from Florida and Texas southward through Mexico and Central America to southern Brazil, Paraguay, and northern Chile. It was intentionally introduced into Fiji, Australia, New Caledonia, Norfolk Island, Java, India, Kenya, Tanzania, Uganda, South Africa, Central African Republic, Zambia, Mauritius, and many Pacific and Indian Ocean islands (Harley and Kassulke 1971). In Florida, it has been recorded from Alachua, Broward, Collier, Dade, Gadsden,
Hillsborough, Lake, Lee, Manatee, Marion, Pinellas, Polk, and Volusia Counties, although it undoubtedly occurs throughout most of the state. In Georgia, its presence was first confirmed in June, 1999 (Baker and Bambara 1999).

Drake and Ruhoff (1965) listed 14 species of Teleonemia from the United States. Most are limited to the southwestern states. Only two of the three species reported from Florida feed on lantana. Several important papers on T. scrupulosa originally appeared using the synonymous name $T$. lantanae or T. vanduzeei.

\section{Description and Biology}

The biology of the lantana lace bug has been studied in Fiji (Simmonds 1929), India (Khan 1945, Roonwal 1952), and Australia (Fyfe 1937).

\section{Adults}

Length 3 to $4 \mathrm{~mm}$; width 1.1 to $1.3 \mathrm{~mm}$. Dorsally, adults are small, brown, elongate- oval lace bugs, appearing slightly expanded near the middle,

1. This document is EENY-246 (originally published as DPI Entomology Circular 156), one of a series of Featured Creatures from the Entomology and Nematology Department, Florida Cooperative Extension Service, Institute of Food and Agricultural Sciences, University of Florida. Published: November 2001. This document is also available on Featured Creatures Website at http://creatures.ifas.ufl.edu. Please visit the EDIS Website at http://edis.ifas.ufl.edu and the Entomology and Nematology Department website at http://entnemdept.ifas.ufl.edu/.

2. D. H. Habeck, retired professor, Department of Entomology and Nematology, F. W. Mead, Florida Department of Agriculture and Consumer Services, Division of Plant Industry, and T. R. Fasulo, Department of Entomology and Nematology, Institute of Food and Agricultural Sciences, University of Florida, Gainesville.

The Institute of Food and Agricultural Sciences (IFAS) is an Equal Employment Opportunity - Affirmative Action Employer authorized to provide research, educational information and other services only to individuals and institutions that function without regard to race, creed, color, religion, age, disability, sex, sexual orientation, marital status, national origin, political opinions or affiliations. For information on obtaining other extension publications, contact your county Cooperative Extension Service office. Florida Cooperative Extension Service / Institute of Food and Agricultural Sciences / University of Florida / Larry R. Arrington, Interim Dean 
and bluntly rounded posteriorly. At low

magnification, most specimens bear a somewhat obscure dark brown " $\mathrm{X}$ " pattern on the tegmina (forewings), usually flanked by a pair of variably shaped brown spots on the swollen middle area of each tegmen. The pronotum has three prominent longitudinal ridges. This species does not have the extended pronotum over the head as seen in many other lace bugs (Short 1998). The antennae are 4-segmented, cylindrical, and with the third segment nearly twice as long as the other three segments combined. For additional descriptive details, see Drake (1918) and Blatchley (1926). Females begin ovipositing five or six days after becoming adults. Adults are active fliers during the summer months (Johnson and Lyon 1991).

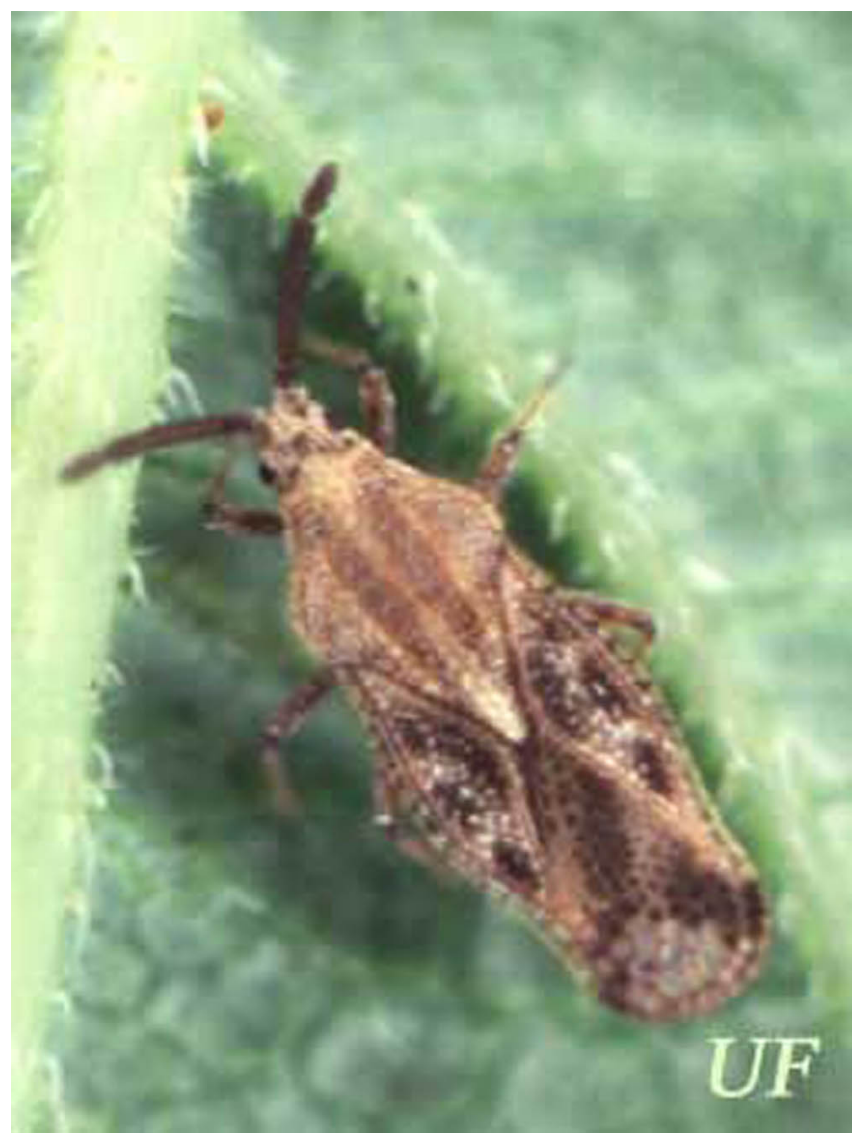

Figure 1. Dorsal view of adult lantana lace bug, Teleonemia scrupulosa Stål. Credits: University of Florida

\section{Nymphs}

In general appearance the nymphs are very different from the adults. They are dull-colored and bear spines which are especially prominent around the abdomen. There are five nymphal instars

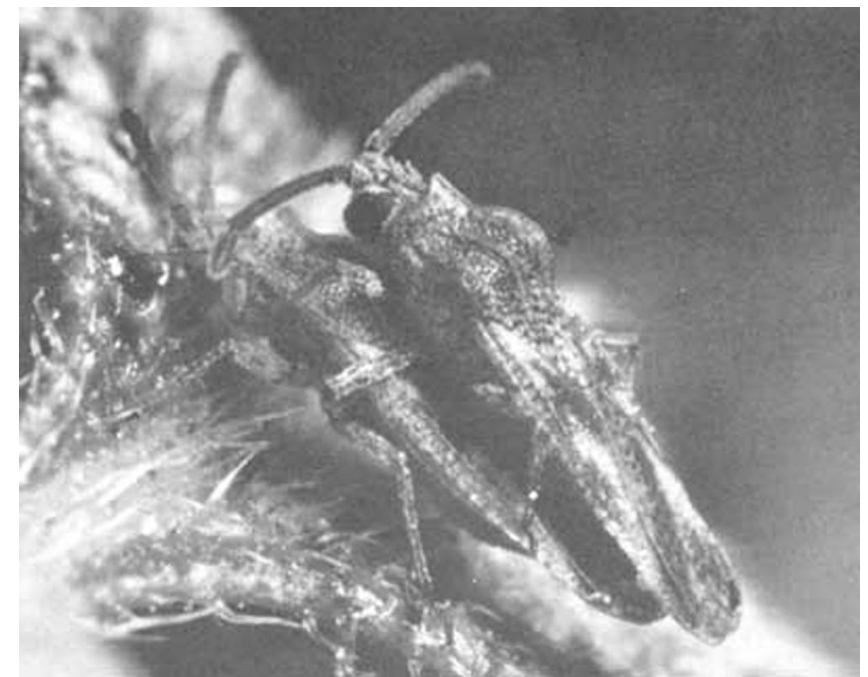

Figure 2. Lateral view of adult lantana lace bugs, Teleonemia scrupulosa Stål. Credits: Division of Plant Industry

characterized by spines around the lateral margin. The wing pads become prominent in the last two instars. Duration of the nymphal stages was 15 to 18 days at 70 to $77^{\circ} \mathrm{F}$ and 12 to 15 days at 77 to $85^{\circ} \mathrm{F}$ (Fyfe 1937).

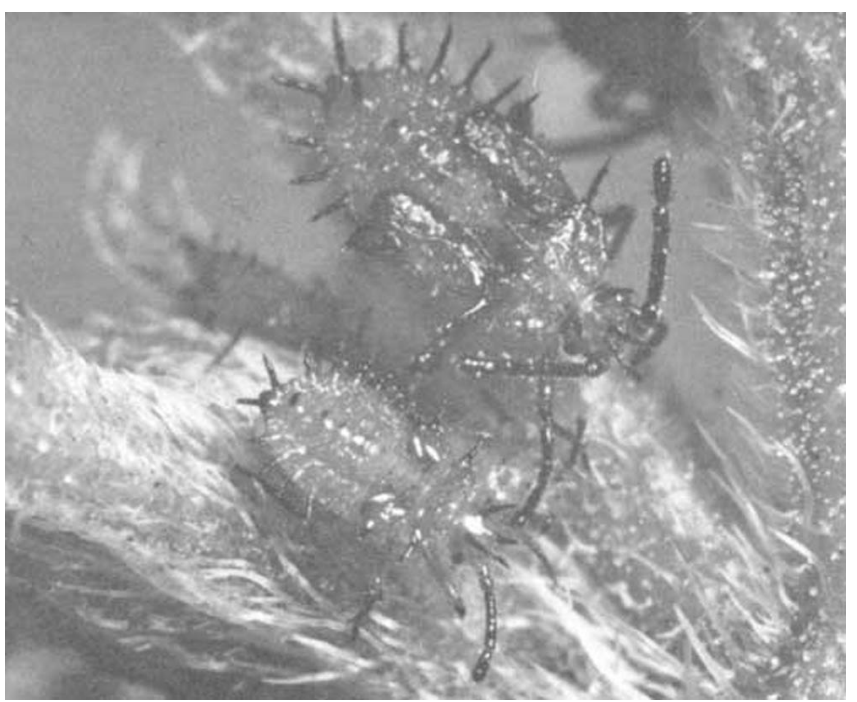

Figure 3. Nymphs of the lantana lace bug, Teleonemia scrupulosa Stål. Credits: Division of Plant Industry

\section{Eggs}

Eggs are inserted into the underside of leaves embedded in the midrib or major veins, usually in clusters of 10 to 30 eggs. The eggs hatch in seven to eight days. Upon hatching the new nymphs aggregate into colonies (Johnson and Lyon 1991). 


\section{Key to Florida Species of Teleonemia}

1. Discoidal area finely pubescent; costal area with wider, predominantly squarish cells; in Florida primarily in the peninsula on lantana .....

Teleonemia scrupulosa Stål

1'. Discoidal area glabrous; costal area with narrower, rectangulate cells . . . . . . . . 2

2. General color dark brown, the elytra with fuscous markings; front margin of pronotum subtruncate, its middle only slightly prolonged forward; coastal areas from Paul Beach County southward; Florida hosts unknown but records elsewhere include Lantana spp., Verbesina sp. and Saccharum officinarum L.... . Teleonemia sacchari (Fabricius)

2'. General color pale brownish yellow, with darker brown markings; front margin of pronotum bisinuate, its middle forming an anteriorly produced triangle; ranges over most of Florida on beauty berry (=French mulberry), Callicarpa americana L..... . Teleonemia belfragii Stål

\section{Host Plants}

About 15 plant species (mostly Lantana and Leucophyllum spp.) are recorded as hosts of the lantana lace bug (Harley and Kassulke 1971). However, damage to plants other than lantana has been slight and transitory with one exception. In East Africa after defoliating lantana, lantana lace bugs moved to sesame (Sesamum indicum L.) causing economic losses to the crop (Greathead 1968). On Lantana, the lace bug feeds on the undersurface of the leaves and greedily attacks newly opened buds and flowers. On purple sage, it feeds on the upper and lower surfaces of the leaves. When on the upper surface, the black excrement spots are readily visible (Johnson and Lyon 1991).

\section{Damage}

Lace bugs feed on the underside of leave, but the damage is very apparent on the upper surface. Damage symptoms bear a strong resemblance to leafhopper damage, but lace bugs produce varnish-like spots on the underside of the leaves. An occasional shed "skin" of a leafhopper nymph is evidence of the cause of that damage. Lace bug damage may resemble mite injury from a distance. However, feeding by mites causes chlorotic flecks in the leaves that are much finer than those caused by lace bugs. Close examination reveals that large numbers of contiguous cells are chlorotic where lace bugs have fed. Positive identification of lace bug damage is confirmed by the presence of brown patches of black droplets of excrement on the undersides of the damaged leaves. Frequently, the cast "skins" of nymphs remain attached to the underside of leaves (Johnson and Lyon 1991). Severe infestations cause the leaves to become almost white and drop from the plants (Short 1998).

\section{Management}

Lace bugs have numerous natural enemies including egg parasites, lacewing larvae, assassin bugs, spiders and predaceous mites (Short 1998).

For more management information see: Insect Management Guide for Commercial Foliage and Woody Ornamental Arthropod Pests (http://edis.ifas.ufl.edu/IG012).

\section{Selected References}

Baker JR, Bambara SB. (11 June 1999). New state record for a lace bug on lantana. North Carolina Pest News. http://ipm.ncsu.edu/current_ipm/99PestNews/ 99News8/ornament.html (31 October 2001).

Blatchley WS. 1926. Heteroptera or True Bugs of Eastern North America, with Especial Reference to the Faunas of Indiana and Florida. Nature Publ. Co., Indianapolis. 1116 p.

Drake CJ. 1918. The North American species of Teleonemia occurring north of Mexico. Ohio Journal of Science 18: 323-332.

Drake CJ, Ruhoff FA. 1965. Lacebugs of the world, a catalog (Hemiptera: Tingidae). U.S. Natural History Museum Bulletin 243: 1-634.

Fyfe RV. 1937. The lantana bug, Teleonemia lantanae Distant. Journal of the Council Science and Ind. Research 10: 181-186. 
Greathead DJ. 1968. Biological control of

Lantana. A review and discussion of recent

developments in East Africa. Pest Articles and News

Summaries (Centre for Overseas Pest Research,

London) (C) 14: 167-175.

Harley KLS, Kassulke RC. 1971. Tingidae for biological control of Lantana camara (Verbenaceae). Entomophaga 16: 389-410.

Johnson WT, Lyon HH. 1991. Insects that Feed on Trees and Shrubs. Cornell University Press.(2nd ed. rev.) Ithaca, NY. 560 p.

Khan AH. 1946. On the lantana bug (Teleonemia scrupulosa Stål). Indian Journal of Entomology 6: 149-161.

Roonwal ML. 1952. The natural establishment of an imported insect in India. The lantana bug, Teleonemia scrupulosa Stål (=lantanae Distant; Hemiptera, Tingidae) with a description of its eggs, nymphs, and adult. Journal of the Zoological Society of India 4: 1-16.

Short DE, Mizell RF, Fasulo TR. (1998). Woodybug: A knowledgebase of pest and beneficial arthropods of Florida woody ornamentals. UF/IFAS. SW-119.

Simmonds HW. 1929. The life history of Teleonemia lantanae. Agric. J. Department of Agriculture, Fiji Isl. 2: 36-39. Stål C. 1873. Enumeratio Hemipterorum 3. Kongl. Vet.-Akad. Handl. 11: 1-163. 